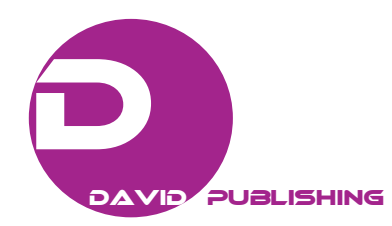

\title{
Solar Sludge Drying Technology and Dried Sludge as Renewable Energy-Closing the Loop
}

\author{
Osvaldo Garanto \\ PESA MEDIOAMBIENTE SAU., (formerly named Passavant España SA), Sant Cugat del Vallès 08174, Spain
}

\begin{abstract}
The biggest problem in wastewater treatment is what can be done with the sewage sludge. Generally, there are few possibilities to manage it such as landfill, incineration or use it as a fertiliser in agriculture with limited amount. Nowadays, there is a simple technology that allows a very costly effective transformation from dewatered sewage sludge into a renewable energy resource. Sewage sludge contains water mostly which can be reduced by common dewatering processes until a DS (dry solids) concentration to about $25 \%$. In this condition, the sludge can be incinerated, but the energy that can be obtained from the burning may be equal to the required one to evaporate the accompanying water. So, another reduction on water content is required until the mass contains $90 \%$ DS under which the calorific value will be increased to about $10 \mathrm{MJ} / \mathrm{kg}$. Then, the sewage sludge can be considered as a clear substitute for coal with the advantage of a renewable and carbon dioxide neutral $\mathrm{CO}_{2}$ emissions.
\end{abstract}

Key words: Sewage sludge, sludge thermal drying, renewable energy, neutral carbon dioxide, alternative fuels, saturated steam cycle.

\section{Introduction}

Nowadays, a problem that needs to be considered carefully is the efficient and environmentally sound management of the sludge generated by the waste water treatment plants [1]. Several sludge treatment solutions are available, such as landfill disposal, agricultural application, composting or thermal drying (Fig. 1).

The sludge has been used as fertilizer in agriculture for decades depending on whether its composition is suitable or not. If it is not, then it is sent to a landfill as solid waste.

When in certain areas, there was a choice of several wastes that could be applied on the soil, composting was the solution resulting in a stabilized product which could be packed and marketed.

As a result of this overuse of agricultural land, there are lots of areas where the sludge application on the soil is no longer allowed.

Corresponding author: Osvaldo Garanto, CTO and execution manager, M.Eng., research field: agricultural engineering.
In such scenario, it is compulsory to improve new technical solutions which have to be cost-effective, getting an overall cost optimization, easy management and low cost of operation and maintenance as well as safety for operators and environmentally friendly. Passavant's Solar Sludge Drying System has been developed to provide this solution.

\section{Solar Sludge Drying System}

Sewage sludge as withdrawn from the treatment process contains water mostly. Common dewatering processes reduce the water content, increasing the DS (dry solids) concentration up to $25 \%$.

At $25 \%$ DS ( $75 \%$ water), the energy content of dewatered sludge is roughly balanced, that is to say, if sludge with this water content is incinerated, the energy that can be obtained from burning the organics is about the same as it is required to evaporate the accompanying water [2].

A further reduction of the water content is only possible through sludge drying. The advantage of sludge drying is, that not only is the mass reduced significantly, but also at $90 \%$ dry solids, the calorific 


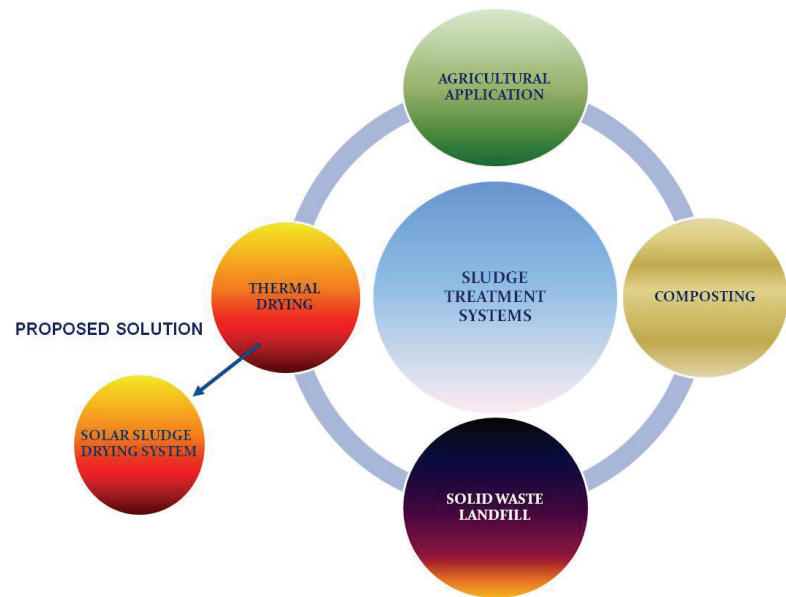

Fig. 1 Solar Sludge Drying System. A new solution for sludge management.
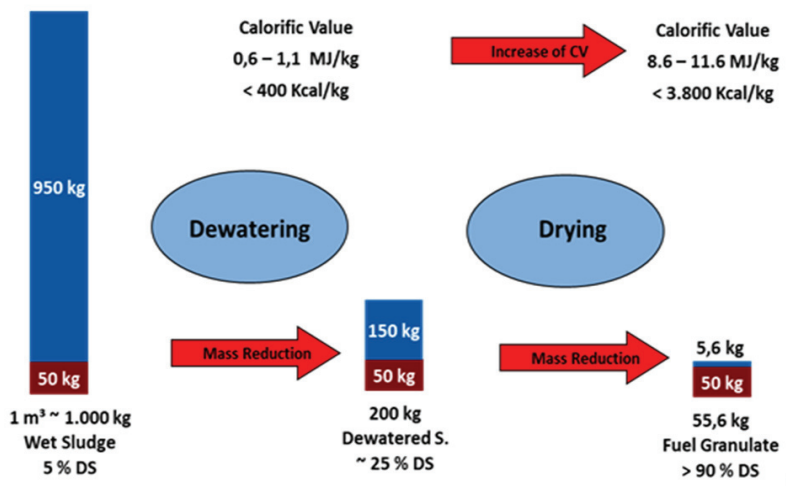

Fig. 2 The change of mass and calorific value [2].

Table 1 Dried sewage sludge as fuel [2-4].

\begin{tabular}{ll}
\hline Fuel & Lower calorific value $(\mathrm{MJ} / \mathrm{Kg})$ \\
\hline Sludge $85 \% \sim 92 \%$ DS & $8.9 \sim 12.5 \sim 15.8$ \\
Dry wood & $15.5 \sim 19$ \\
Mineral coal & $\sim 29$ \\
Brown coal & $8.4 \sim 16.8$ \\
\hline
\end{tabular}

value is increased to about $12.5 \mathrm{MJ} / \mathrm{kg}$ (Fig. 2).

When comparing the calorific value of dried sewage sludge with other energy resources, it shows that dried sewage sludge can be an attractive alternative energy.

This means sewage sludge, if dried to $90 \%$ DS, is not waste, but an attractive alternative energy as shown in Table 1.

As sewage sludge has its source in food products, it is also a renewable and carbon dioxide neutral energy. That means that using dried sludge as a substitute fuel not only reduces the primary energy consumption but also avoids $\mathrm{CO}_{2}$ emissions from fossil fuels.

According to Table 1, there are some additional conclusions to take into consideration:

(1) $2 \mathrm{t}$ of dried sewage sludge equalizes $1 \mathrm{t}$ of mineral coal in calorific value;

(2) $1 \mathrm{t}$ of sewage sludge used as fuel avoids $0.48 \mathrm{t}$ of $\mathrm{CO}_{2}$ emissions from fossil fuels;

(3) Cement and power plants can reduce their demand of primary energy and also reduce $\mathrm{CO}_{2}$ Emissions [5, 6]. In Spain, at Alicante's cement factory, it was substituted part of the coal used as primary fuel by dried sewage sludge. Based on a heat content of the substituted coal of $26 \mathrm{GJ} / \mathrm{t}$ and a ratio of $93 \mathrm{~kg} \mathrm{CO} / \mathrm{t}$ of coal, the following environmental indicators were achieved:

- The waste energy from the cement factory used for thermal drying implied 46 million therms gained annually, equivalent to around $18,000 \mathrm{t} / \mathrm{CO}_{2}$;

- The energy supplied by the sludge combusted in the kiln (average value of $12.5 \mathrm{MJ} / \mathrm{kg}$ ) implied 53 million therm gained annually, equivalent to $20,500 \mathrm{t}$ of $\mathrm{CO}_{2}$.

\section{Process Description}

The following flow chart (Fig. 3) will help to describe the process, as well as, show some data of one project designed by Pesa Medioambiente Sau (formerly named Passavant España SA) which will be used as an example. At the same time, Fig. 4 describes the whole system for a better understanding.

The dewatered sludge between $20 \%$ and $30 \%$ dry solids content obtained in the WWT (waste water treatment) Plant is fed into containers or trucks and brought to the solar sludge drying plant, where is stored in a reception tank which has enough capacity to overcome long weekends (5 to 10 days) as minimum, as well as, to balance the difference that there is between the plant average treatment capacity and the sludge production.

Considering a sludge production of 25,454 t/year with a dry solids content of $22 \%$ DS, It is required a 


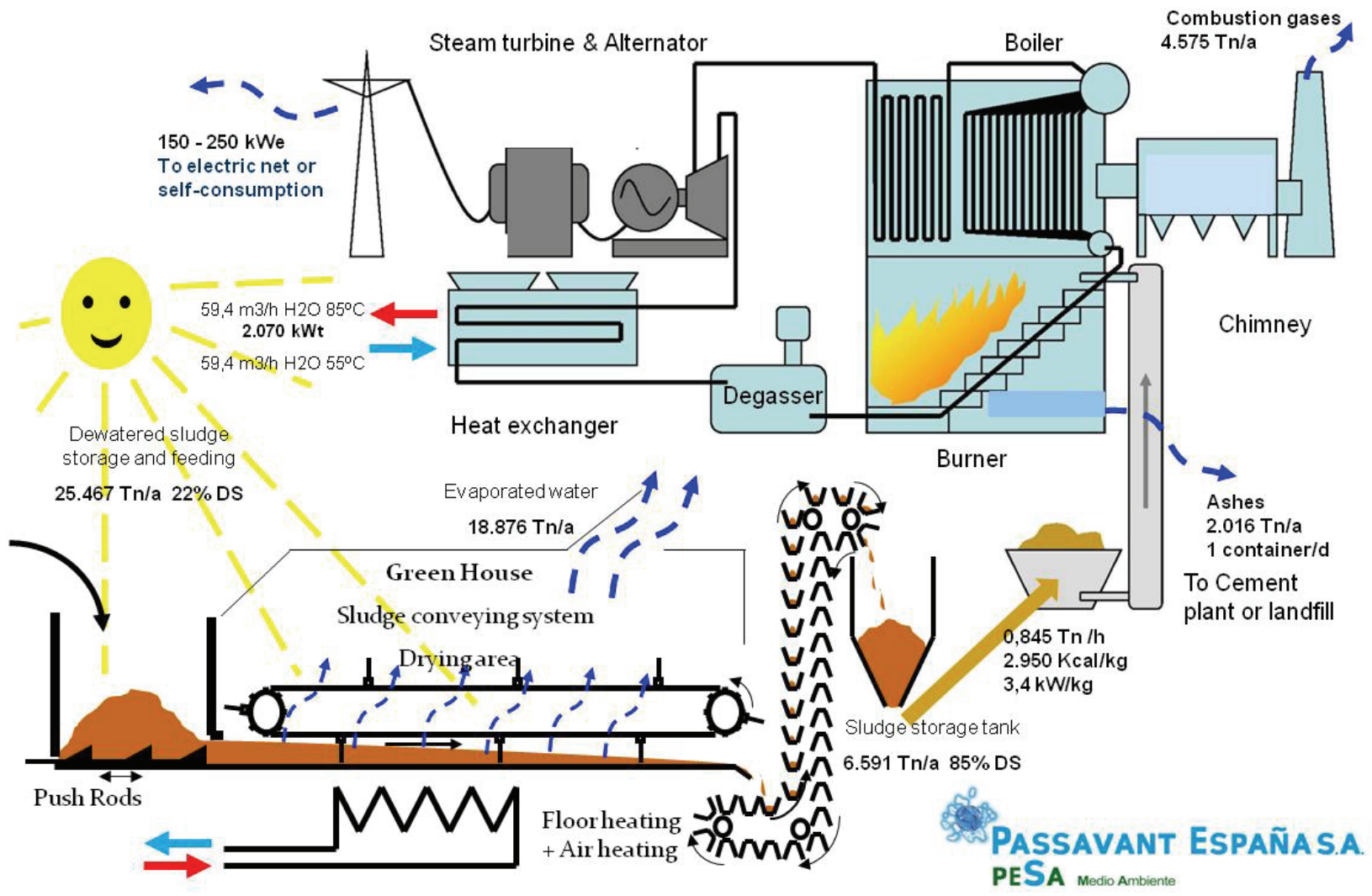

Fig. 3 Flow chart.

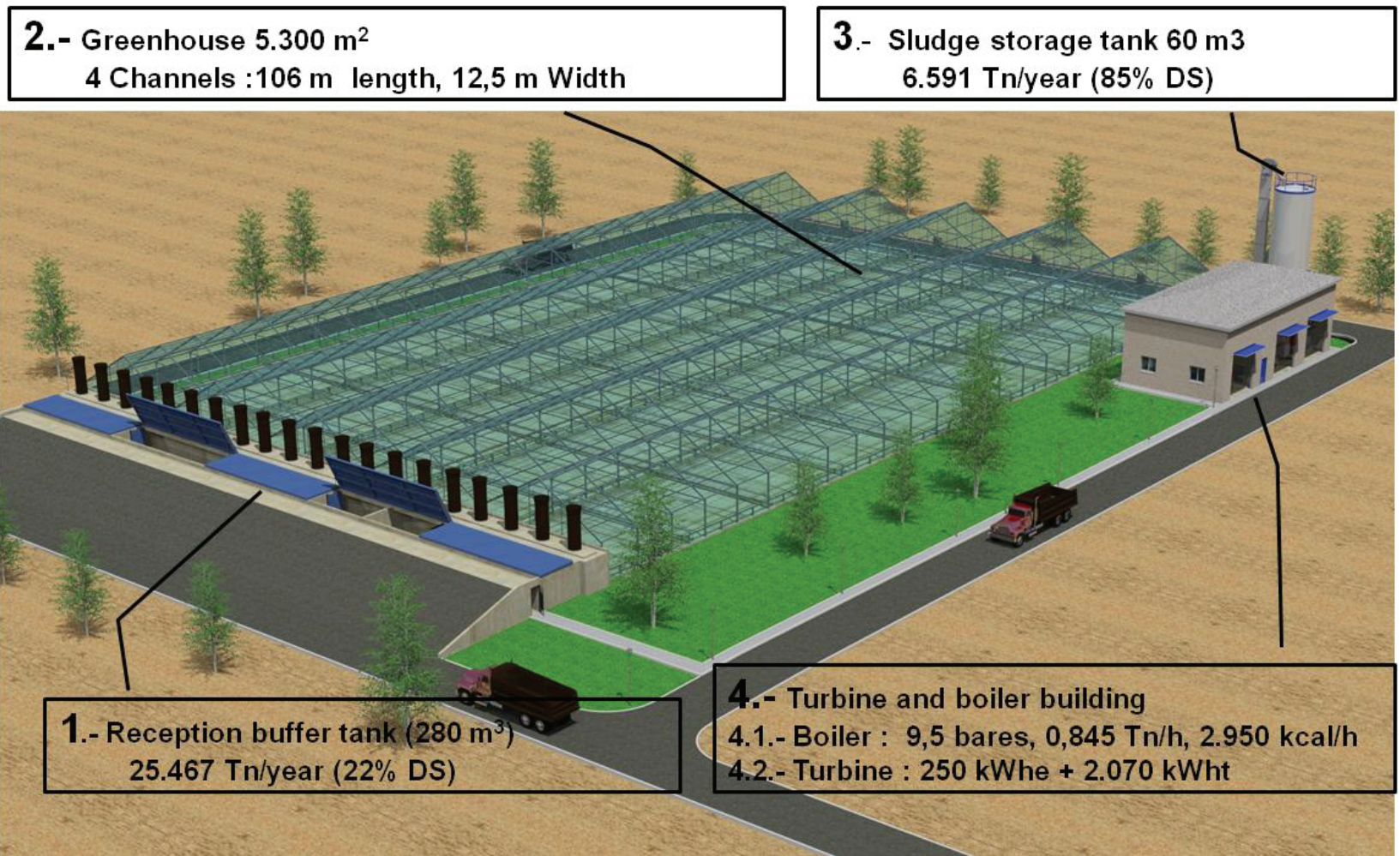

Fig. 4 Solar sludge drying plant $(25,467 \mathrm{t} / \mathrm{year})$ with energy recovery using sewage sludge as fuel granulate. 
concrete buffer tank with a total volume of $210 \mathrm{~m}^{3}$, divided in three parts of $70 \mathrm{~m}^{3}$ each.

This buffer tank is provided with a push rood bottom system which makes some backwards and forwards movements in order to push the sludge located at the bottom of the tank into the drying area (Fig. 5).

The drying area or system itself consists of a greenhouse, equipped with a turning and conveying automatic device of sludge that conveys it from one side to the other one. Constant movement of the sludge prevents formation of clusters and ensures frequent renewing of the surface in order to increase the evaporation.

Solar radiation is used to evaporate water. In addition, there is also the possibility to install a floor and air heating system that will use the cooling water at $90{ }^{\circ} \mathrm{C}$ from a CHP (combined heat and power) unit, whenever the latter exists or it is available.
In the project mentioned before like an example, it was foreseen to recover the thermal energy obtained from the water used to condensate the saturated steam at the outlet of a steam turbine.

The water evaporated from the sludge during the drying process leaves the greenhouse through the roof openings or vents provided to do this.

It takes some days to dry the sludge, depending on the weather conditions and the amount of residual thermal energy available from the CHP unit, whenever this is available.

The required area for drying 25,454 t/year from $22 \%$ DS to $85 \%$ DS is $5,300 \mathrm{~m}^{2}$ (Fig. 6), divided in three different channels of $12.5 \mathrm{~m}$ in width and $96 \mathrm{~m}$ in length, and equipped with a floor heating system which will use recovered cooling water at $85{ }^{\circ} \mathrm{C}$ (Fig. 7) obtained from the cooling system to condensate the low pressure saturated steam at the outlet of a turbine.

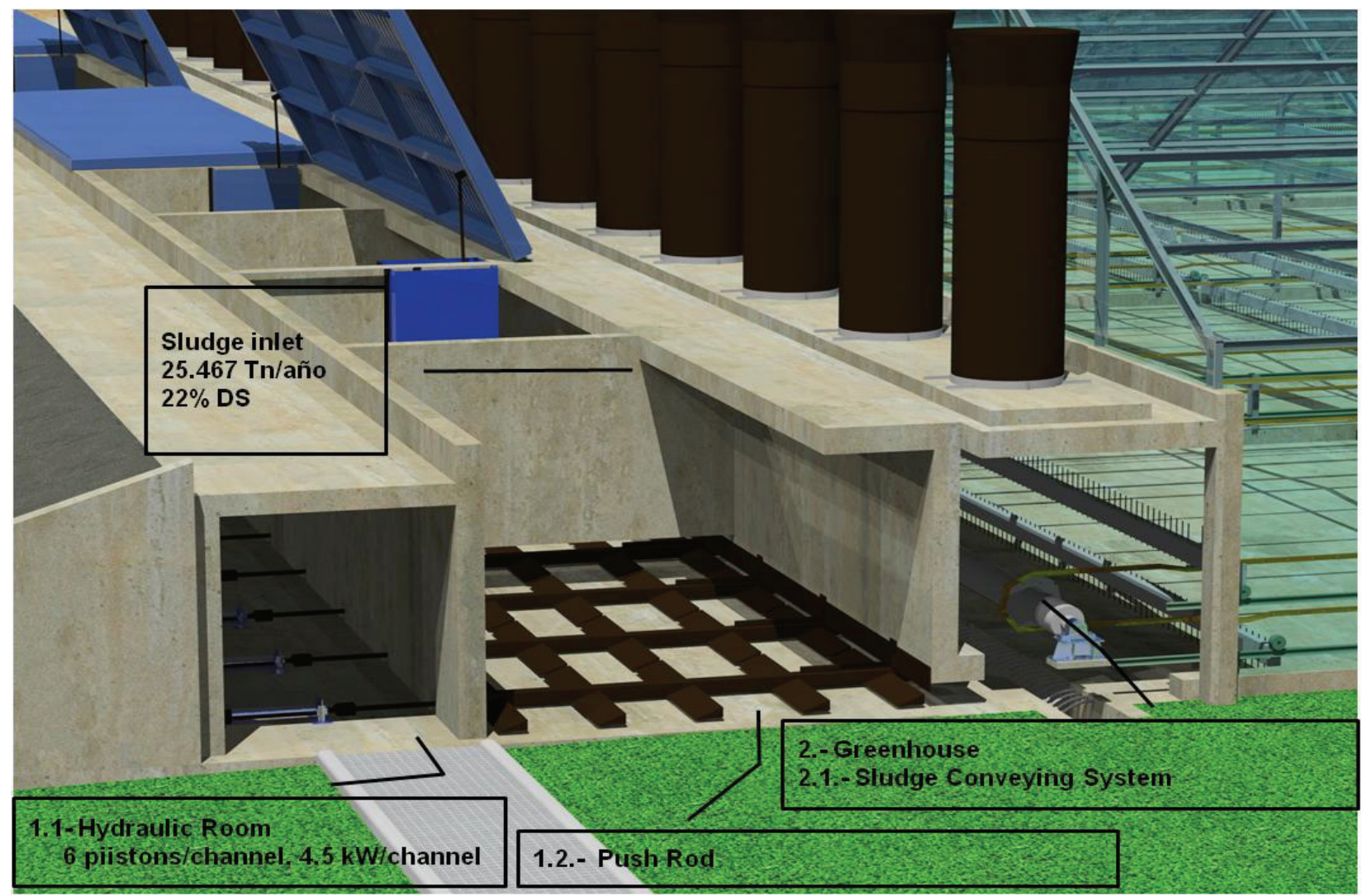

Fig. 5 Reception buffer tank. 


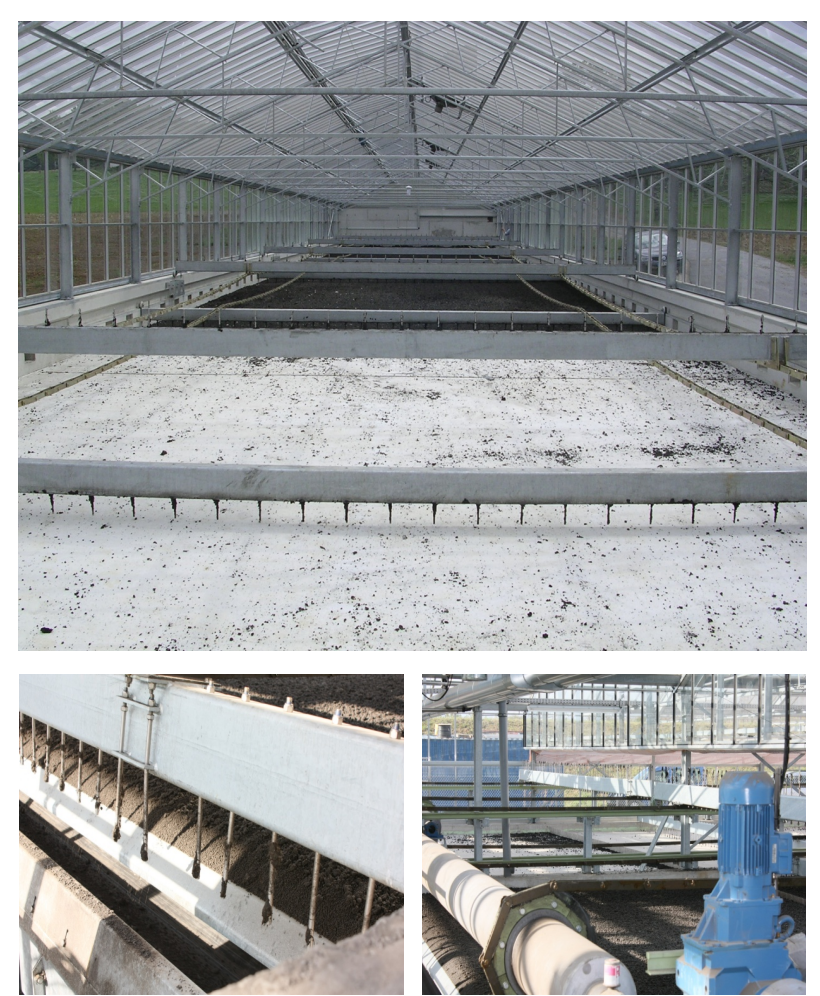

Fig. 6 Greenhouse. Conveying and turning automatic device of sludge.

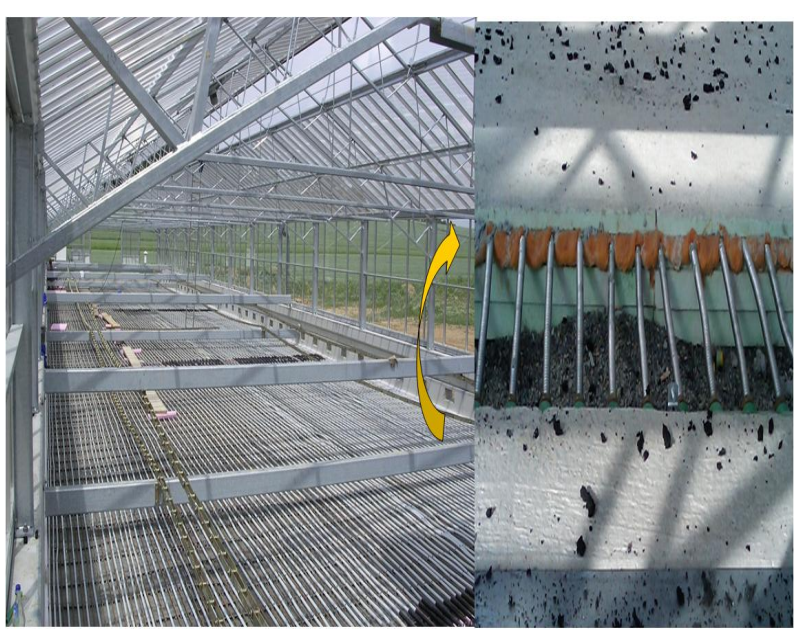

Fig. 7 Floor heating system: 1 Ut Pipe $1 / 2 \% / 10 \mathrm{~cm}$ with hot running water from $55^{\circ} \mathrm{C}$ to $90{ }^{\circ} \mathrm{C}$.

The amount of dried sludge at $85 \%$ DS will be $6,591 \mathrm{t} /$ year, whose calorific value will be around $2,950 \mathrm{kcal} / \mathrm{kg}$. At the end of the drying area, it drops into a bucket conveyor and is stored in a silo (Fig. 8).

In order to recover the calorific power of the dried sludge, the system will be equipped with a boiler which will use this dried sludge as fuel, capable of burning $0.85 \mathrm{t} / \mathrm{h}$ of dried sludge, obtaining $3.6 \mathrm{t} / \mathrm{h}$ of saturated steam at 9.5 barg and $178^{\circ} \mathrm{C}$ (Fig. 9).

The high pressure saturated steam will be used in a turbine, where the pressure will be reduced from 9.5 barg to 1.25 barg $\left(105^{\circ} \mathrm{C}\right)$, obtaining as a result both, electric power production from 150 to $250 \mathrm{kWh}$ (Fig. 10) which will be used in the plant or sent to the electrical net, and low pressure steam.

The low pressure saturated steam at the outlet of the turbine, enters to an exchanger where it will be condensate into water. At the same time, the $59.5 \mathrm{~m}^{3} / \mathrm{h}$ at 2.5 barg of cooling water used to condensate the steam is going to increase its temperature from $55^{\circ} \mathrm{C}$ to $85{ }^{\circ} \mathrm{C}$. The condensate at $105{ }^{\circ} \mathrm{C}$ returns to the boiler.

The hot water obtained in the exchanger at $85^{\circ} \mathrm{C}$ is sent to the floor heating system which helps to the sludge water evaporation and reduces the required area for drying the sludge.

\section{Technical and Economical Comparison among Several Sludge Thermal Drying Systems}

According to both technical and economical, ratios shown in Tables 2 and $3[6,7]$ as well as the performances obtained in Passavant's plants, it may be stated that the systems based on a low temperature thermal drying, those where operation temperature is lower than $80^{\circ} \mathrm{C}$ (Table 2), are more cost-effective,

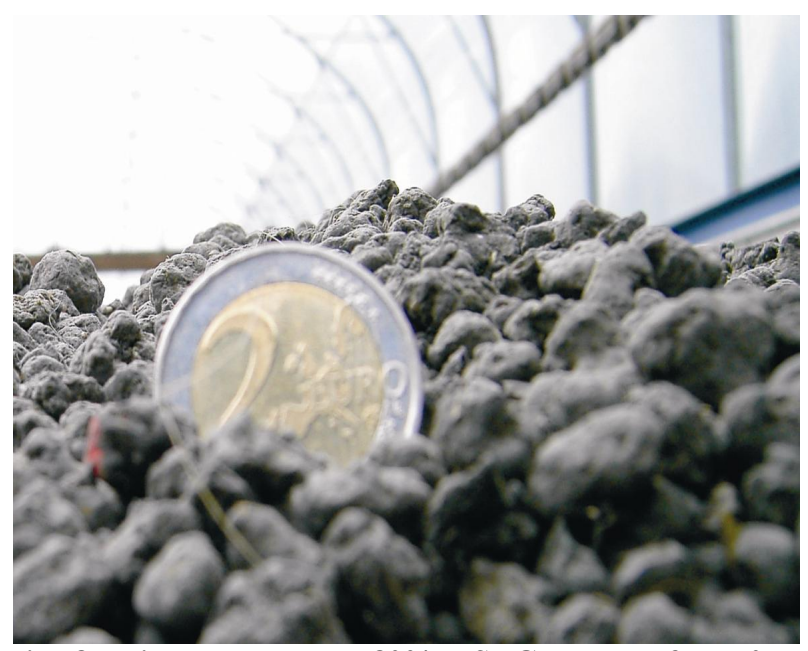

Fig. 8 Final product: $>80 \%$ DS. Granulate from 0 to $8 \mathrm{~mm}$ in diameter. 


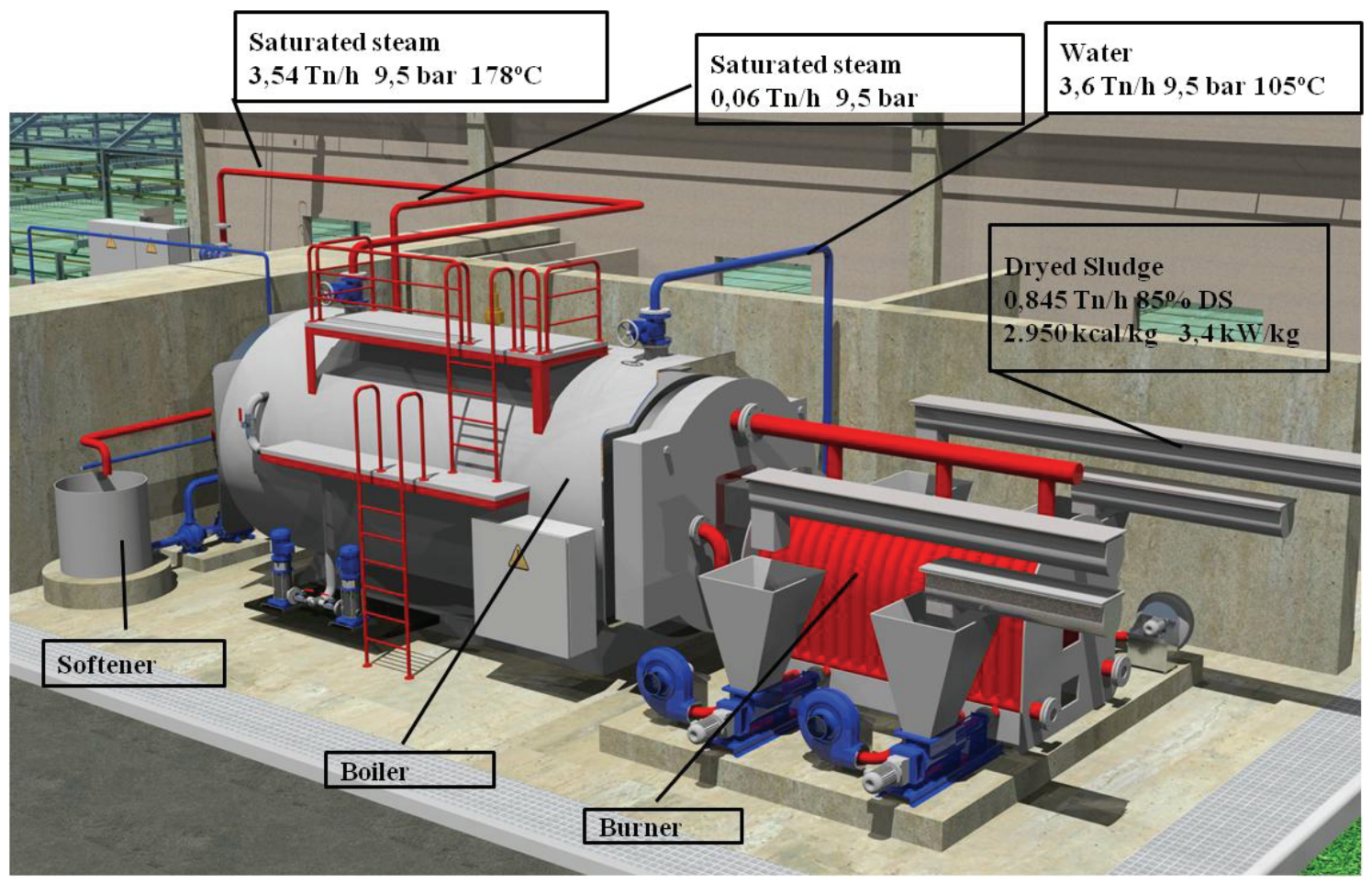

Fig. 9 Boiler and burner.

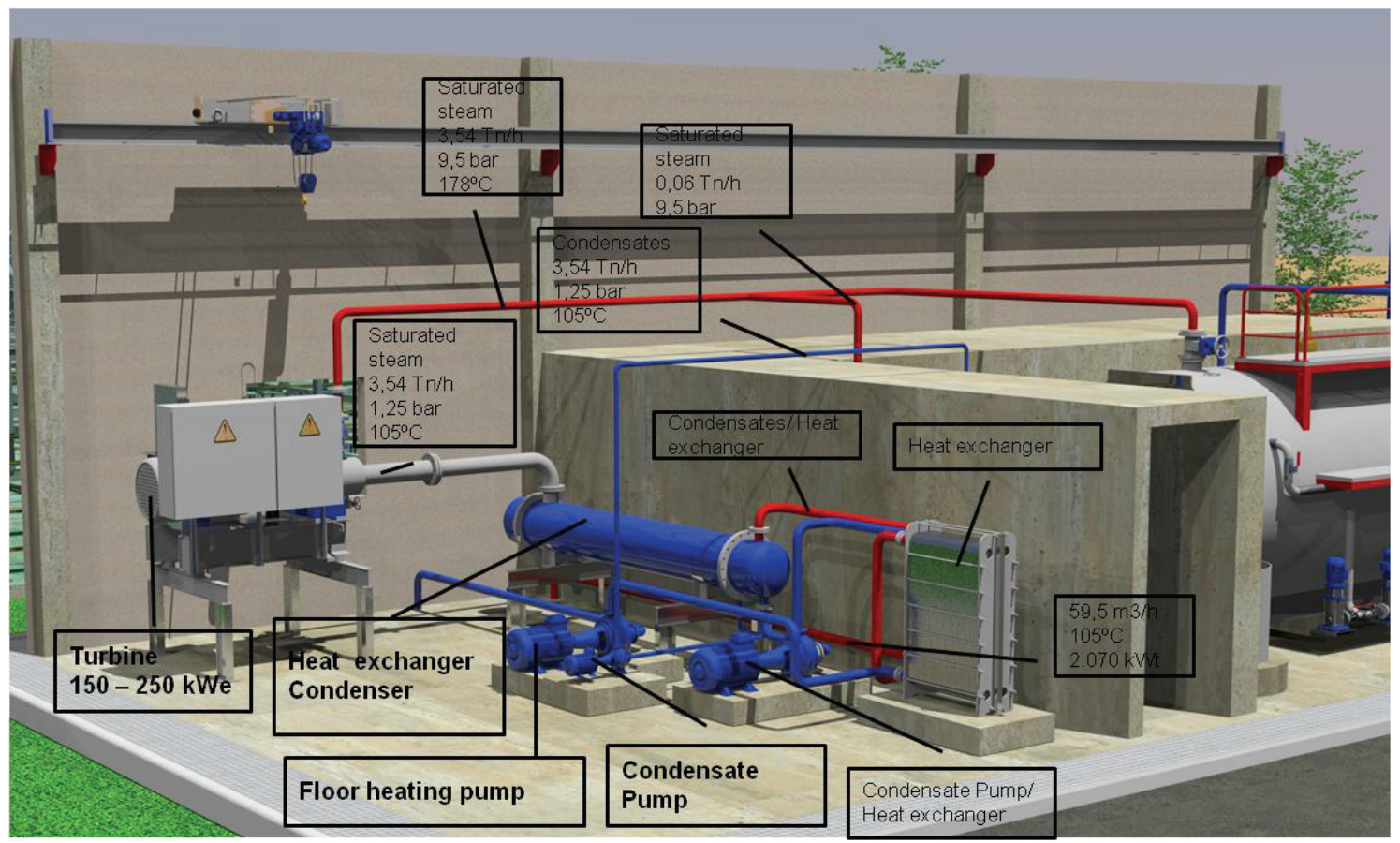

Fig. 10 Turbine.

getting an overall cost optimization, easy management and low cost of operation and maintenance, as well as they are safer for operators and more environmentally friendly than the ones which require high operation temperature.

Moreover, taking in consideration that the sludge disposal in a waste landfill may have a management cost between 70 and $160 € / \mathrm{t}$ which depends on its 
Table 2 Technical comparison among several sludge thermal drying systems [7].

\begin{tabular}{|c|c|c|c|c|c|c|c|}
\hline & $\begin{array}{l}\text { Convection } \\
\text { drum dryer }\end{array}$ & $\begin{array}{l}\text { Conduction } \\
\text { rotary dryer }\end{array}$ & $\begin{array}{l}\text { Vertical dryer } \\
\text { trays }\end{array}$ & Belt dryer & $\begin{array}{l}\text { Thin layer } \\
\text { dryer }\end{array}$ & $\begin{array}{l}\text { Incinerator/ } \\
\text { /fluid bed dryer }\end{array}$ & Passavant \\
\hline $\mathrm{T}^{\mathrm{a}}\left({ }^{\circ} \mathrm{C}\right)$ & $300 \sim 500$ & $100 \sim 130$ & $100 \sim 130$ & $55 \sim 70$ & $200 \sim 270$ & $80 \sim 100 / 900$ & $\begin{array}{l}\text { Weather } \\
\text { conditions }\end{array}$ \\
\hline DS in $(\%)$ & $>20$ & $>20$ & $>20$ & $>20$ & $>5$ & $>25 /<40$ & $>20$ \\
\hline DS out $(\%)$ & $90-95$ & $85 \sim 95$ & $90 \sim 95$ & $85 \sim 95$ & $90 \sim 95$ & $>95$ & $>95$ \\
\hline \multicolumn{8}{|l|}{ Energy: } \\
\hline $\mathrm{kcal} / \mathrm{kg}$ & $750 \sim 900$ & 750 & 750 & $774 \sim 860$ & $750 \sim 1,000$ & $800 \sim 900$ & $860 \sim 1,000$ \\
\hline $\mathrm{kWh} / \mathrm{t}$ & $900 \sim 1,050$ & 900 & 900 & $900 \sim 1,000$ & $900 \sim 1,200$ & $900 \sim 1,000$ & $1,000 \sim 1,160$ \\
\hline \multicolumn{8}{|l|}{ Power : } \\
\hline $\mathrm{kWh} / \mathrm{t}$ & $60-400$ & $80 \sim 150$ & - & $130 \sim 300$ & - & $130 \sim 150$ & $30 \sim 60$ \\
\hline Life (y) & $12 \sim 15$ & $12 \sim 15$ & $12 \sim 15$ & $12 \sim 15$ & $12 \sim 15$ & 25 & 30 \\
\hline $\begin{array}{l}\text { Operation } \\
(\mathrm{h} / \mathrm{y})\end{array}$ & $7,200 \sim 8,000$ & & & 8,000 & & $\begin{array}{l}24 \mathrm{~h} / \mathrm{d} \\
7 \mathrm{~d} / \mathrm{w}\end{array}$ & 8,000 \\
\hline
\end{tabular}

a: both, energy and power, are referred to tones of evaporated water.

Table 3 Economical comparison among several sludge thermal drying systems [8].

\begin{tabular}{|c|c|c|c|c|c|c|}
\hline System & Material & $\begin{array}{l}\text { capacity } \\
10^{3} \mathrm{t} / \mathrm{y}\end{array}$ & $\begin{array}{l}\text { capacity } \\
10^{3} \mathrm{t} \mathrm{DS} / \mathrm{y}\end{array}$ & $\begin{array}{l}\text { Investment } \\
\text { million } €\end{array}$ & $\begin{array}{l}\text { Investment } \\
€ /(\mathrm{t} \cdot \mathrm{DS} / \mathrm{y})\end{array}$ & $\begin{array}{l}\text { Operation } \\
(€ / t \cdot D S)\end{array}$ \\
\hline Thermal drying + burner & Dewatered sludge & $50 \sim 200$ & $11.5 \sim 46$ & $4.8 \sim 13.8$ & $290 \sim 410$ & $105 \sim 130$ \\
\hline Thermal drying $+\mathrm{CHP}$ & Dewatered sludge & $50 \sim 200$ & $11.5 \sim 46$ & $9.6 \sim 27.0$ & $590 \sim 830$ & $40 \sim 110$ \\
\hline $\begin{array}{l}\text { Passavant' solar drying }+ \\
\text { burner }+ \text { steam turbine }\end{array}$ & Dewatered sludge & $10 \sim 50$ & $2.3 \sim 11.5$ & $2.4 \sim 9.0$ & $780 \sim 1,050$ & $60 \sim 105$ \\
\hline $\begin{array}{l}\text { Passavant' solar drying }+ \\
\text { burner }+ \text { steam turbine }\end{array}$ & Dewatered sludge & $50 \sim 200$ & $11.5 \sim 46$ & $9.0 \sim 30.0$ & $660 \sim 1,050$ & $60 \sim 105$ \\
\hline $\begin{array}{l}\text { STC's thermal drying (belt } \\
\text { DRYER) + CHP }\end{array}$ & Dewatered sludge & $10 \sim 47$ & $2.3 \sim 10.8$ & $2.6 \sim 7.8$ & $730 \sim 1,120$ & $60 \sim 140$ \\
\hline $\begin{array}{l}\text { Electric drying with heating } \\
\text { pump }\end{array}$ & Dewatered sludge & $10 \sim 33$ & $2.3 \sim 7.6$ & $1.4 \sim 2.8$ & $360 \sim 610$ & $150 \sim 220$ \\
\hline $\begin{array}{l}\text { Thermal drying + CHP + } \\
\text { gasification }\end{array}$ & Dewatered sludge & $50 \sim 200$ & $11.5-46$ & $14.4 \sim 39.1$ & $850 \sim 1,250$ & $30 \sim 110$ \\
\hline $\begin{array}{l}\text { Supercritic oxidation } \\
\text { (SCWO) }\end{array}$ & Thickened sludge & 90 & 20.7 & 4.3 & 210 & 200 \\
\hline Vertech's oxidation system & Thickened sludge & 622 & 28 & 36.1 & 1,290 & 250 \\
\hline Biomethanisation $+\mathrm{CHP}$ & $\begin{array}{l}\text { FORSU/sludge } \\
80 / 20\end{array}$ & $35 \sim 140$ & $8.1 \sim 32$ & $12.0 \sim 28.8$ & $890 \sim 1,500$ & $70 \sim 140$ \\
\hline $\begin{array}{l}\text { Preliminary drying }+ \\
\text { incinerator }+ \text { steam turbine }\end{array}$ & Dewatered sludge & $50 \sim 200$ & $11.5 \sim 46$ & $25.2 \sim 72.7$ & $1,590 \sim 2,180$ & $220 \sim 320$ \\
\hline $\begin{array}{l}\text { Preliminary drying }+ \\
\text { incinerator (Dordrecht) }\end{array}$ & Dewatered sludge & 240 & 55.2 & 77.5 & 1,400 & 250 \\
\hline Incinerator + steam turbine & Dewatered sludge & $50 \sim 200$ & $11.5 \sim 46$ & $29.4 \sim 85.3$ & $1,850 \sim 2,570$ & $250 \sim 350$ \\
\hline Windrow composting & Dewatered sludge & $10 \sim 150$ & $2.3 \sim 34.5$ & $0.5 \sim 3.1$ & $90 \sim 240$ & $40 \sim 85$ \\
\hline Tunnel composting & Dewatered sludge & $10 \sim 150$ & $2.3 \sim 34.5$ & $2.5 \sim 18.3$ & $530 \sim 1,080$ & $90 \sim 170$ \\
\hline Channel composting & Dewatered sludge & $10 \sim 150$ & $2.3 \sim 34.5$ & $1.2 \sim 7.8$ & $220 \sim 510$ & $60 \sim 140$ \\
\hline
\end{tabular}

Note: FORSU means organic fraction of municipal wastes.

composition, distance to the landfill, yearly production or even if there are available or no other possible solutions such as agricultural use in the same area, the low temperature thermal drying systems provide the cheapest operation and investment cost for plants whose treatment capacity is from 50,000 to $200,000 \mathrm{t} / \mathrm{y}$.
On the other hand, this kind of treatment is also an effective one when there is no possibility or there is a strong regulation in the area about the number of tons of sludge that can be used in agriculture.

The low thermal energy required for Passavant's system $(1,000$ to $1,160 \mathrm{kWh} / \mathrm{t})$ to evaporate sludge's water, together with the lowest power consumption 30 
to $60 \mathrm{kWh} / \mathrm{t}$, makes it to provide the best cost-effective solution whenever the space is not limited.

\section{Conclusions}

Having been described before technically and economically the sludge solar drying system of Passavat, the following features are the most important ones:

- System fully automatic and continuous process. The sludge is fed on one side of a greenhouse and is moved during the drying process to the other side;

- Sludge is dried from $18 \%$ DS to $>95 \%$ DS;

- Sludge is dried using solar radiation and, if available, additional heat, e.g., from CHP units or steam turbines;

- The sludge thickness is reduced by drying from $\sim 0.15 \mathrm{~m}$ (6 in.) at feed side to $\sim 0.038 \mathrm{~m}$ (1.5 in.) at outlet side;

- Distribution/turning inside greenhouse is done using chain scraper and harrows;

- No dirt or dust problems due to smooth conveying system;

- No odor problems due to thin sludge layer and continuous turning (aerobic conditions);

- Low and easy maintenance;

- Very low investment 660 1,050 €/t DS cost and very low operational cost $60 \sim 105 € / \mathrm{t} \mathrm{DS}$;

- Width $\sim 10 \mathrm{~m}$ to $12.5 \mathrm{~m}$, length $50 \sim 120 \mathrm{~m}$ per channel;

- No pollution and no contact with sludge;

- Use of additional heat can reduce required surface by $75 \%$;

- Use of additional heat, e.g., hot water at $85^{\circ} \mathrm{C}$, enables high DS concentration (>90\%) and reduce the required surface;

- High evaporation rate and efficiency due to thin sludge layers;

- No sticking of sludge, as sludge is constantly moved;
- $19 \%$ higher surface area due to conveying and turning automatic device;

- Very low electric energy consumption (30 60 kWh/t evaporated water);

- Passavant's drying system is the most economical system on the market.

\section{References}

[1] Uhre, L., and Meozzi, P. 1997. Sludge Treatment and Disposal. Management Approaches and Experiences. Environmental Issues Series No. 7. ISWA's working group on sewage \& waterworks sludge and European Environment Agency. Copenhagen. Accessed August 8, 2016. http://www.eea.europa.eu/publications/GH-10-97106-EN-C/download.

[2] Zizmann, R., Wicht, H., and Fassbender, D. 2009. "El Método Roediger EDZ de Secado de Fangos de Aguas Residuales". Presented at V Jornadas Técnicas de Saneamiento y Depuración. Eficiencia Energética en el Tratamiento de las Aguas Residuales, November 26, 2009. (in Spainish)

[3] Ortega, E., and Sobrados, L. 2009. "Caracterización de los Lodos de Depuradora Generados en España". Ministerio de Medio Ambiente y Medio Rural y Marino. Madrid. Accessed August 8, 2016. http://www.magrama. gob.es/es/calidad-y-evaluacion-ambiental/temas/prevenci on-y-gestion-residuos/Caracterizaci\% $\% 3 \% \mathrm{~B} 3 \mathrm{n}$ _de_los_lo dos_de_depuradoras_generados_en_Espa\%C3\%B1a_(NI PO_770-10-256-5)_tcm7-183315.pdf. (in Spanish)

[4] Bonmatí, A., and Burgos, L. 2012. Anàlisis del PCI i PCS de Diferents Mostres de Fangs de Depuradora. Mollet del Vallès: GIRO. (in Spanish)

[5] CEMBUREAU (The European Cement Association). 1999. Environmental Benefits of Using Alternative Fuels in Cement Production. Brussels: CEMBUREAU. Accessed August 8, 2016. http://www.wbcsdcement.org/ pdf/tf2/CEMBUREAU.pdf.

[6] Permuy, D., and Arauzo, I. 2012. "Biomass Low Temperature Drying. A Successful Case Sludge Management in a Cement Factory to Meet Kyoto Protocol." Presented at European Drying Conference-EuroDrying' 2011, Balearic Island, Spain.

[7] Sánchez, J. 2004. "Estudio de las Tecnologías de Secado de Biosólidos Procedentes de EDAR". Proyecto fin de carrera, Escuela Superior de Ingenieros, Universidad de Sevilla. Accessed August 8, 2016. http://bibing.us.es/proyectos/abreproy/3779/fichero/Capit ulo_30.pdf. (in Spanish)

[8] Fundación Centro Canario del Agua. n.d. "Análisis de la Situación y Posible Evolución de las Tecnologías Para el 
Tratamiento de Lodos de Depuración.” Accessed August

8, 2016. http://fcca.es/documentos/05_documentos_
por_temas/Depuracion $\% 20 y \% 20$ reutilizacion $\% 20 /$ Tecnolo giaslodos.pdf. (in Spainish) 